\title{
Periodontal Dressing-containing Green Tea Epigallocathechin gallate Increases Fibroblasts Number in Gingival Artifical Wound Model
}

\author{
Ardisa U. Pradita ${ }^{1}$, Agung P. Dhartono ${ }^{1}$, Catur A. Ramadhany ${ }^{1}$, Ali Taqwim² \\ ${ }^{1}$ Undergraduate Program, Faculty of Dentistry, University of Jendral Soedirman, Purwokerto 53146, Indonesia \\ ${ }^{2}$ Faculty of Dentistry, University of Jendral Soedirman, Purwokerto 53146, Indonesia \\ Correspondence e-mail: ardisaulfahpradita@yahoo.co.id
}

\begin{abstract}
Green tea leaf (Camellia sinensis) is one of herbal plants that is used for traditional medicine. Epigallocatechin gallate (EGCG) in green tea is the most potential polyphenol component and has the strongest biological activity. It is known that EGCG has potential effect on wound healing. Objective: This study aimed to determine the effect of adding green tea EGCG into periodontal dressing on the number of fibroblasts after gingival artificial wound in animal model. Methods: Gingival artifical wound model was performed using $2 \mathrm{~mm}$ punch biopsy on 24 rabbits (Oryctolagus cuniculus). The animals were divided into two groups. Periodontal dressing with EGCG and without EGCG was applied to the experimental and control group, respectively. Decapitation period was scheduled at day 3 , 5, and 7 after treatment. Histological analysis to count the number of fibroblasts was performed. Results: Number of fibroblasts was significantly increased in time over the experimental group treated with EGCG periodontal dressing compared to control $(p<0.05)$. Conclusion: EGCG periodontal dressing could increase the number of fibroblast, therefore having role in wound healing after periodontal surgery in animal model.
\end{abstract}

\begin{abstract}
ABSTRAK
Periodontal dressing dengan kandungan epigallocathechin gallate teh hijau meningkatkan sel fibroblas setelah perlukaan gingiva. Daun teh hijau (Camellia sinensis) merupakan salah satu tanaman herbal yang digunakan sebagai obat tradisional. Epigallocatechin gallate (EGCG) pada daun teh hijau adalah polifenol yang paling poten dan memiliki aktivitas biologis paling kuat. Kandungan EGCG berpotensi untuk mempercepat penyembuhan luka. Tujuan: Penelitian ini bertujuan untuk membuktikan pengaruh penambahan EGCG daun teh hijau pada periodontal dressing terhadap jumlah sel fibroblas pasca perlukaan gingiva. Metode: Penelitian ini menggunakan 24 ekor kelinci (Oryctolagus cuniculus) perlukaan pada gingiva rahang bawah menggunakan punch biopsy berdiameter $2 \mathrm{~mm}$. Hewan coba dibagi menjadi 2 kelompok, terdiri dari kelompok kontrol yang diaplikasikan periodontal dressing tanpa penambahan EGCG daun teh hijau dan kelompok perlakuan yang diaplikasikan periodontal dressing dengan penambahan EGCG daun teh hijau. Setiap kelompok dibagi menjadi 3 sub kelompok sesuai periode dekapitasi hewan coba yaitu hari ke-3, ke-5 dan hari ke-7 setelah perlukaan. Pengamatan histologis dilakukan dengan menghitung jumlah sel fibroblas. Hasil: Hasil uji statistik menunjukkan terdapat perbedaan bermakna jumlah sel fibroblas antara 3 sub kelompok (ANOVA, $p<0,05$ ). Simpulan: Penambahan EGCG daun teh hijau pada periodontal dressing dapat meningkatkan jumlah sel fibroblas pasca perlukaan gingiva.
\end{abstract}

Key words: EGCG, fibroblast, green tea, periodontal dressing, wound healing

\section{PENDAHULUAN}

Daun teh hijau (Camellia sinensis) merupakan salah satu tanaman herbal yang digunakan sebagai obat tradisional yang banyak digunakan karena banyaknya kandungan bahan aktif yang lebih besar daripada teh jenis lain. ${ }^{1}$ Salah satu kandungan daun teh hijau adalah katekin. Jenis katekin dalam daun teh hijau yaitu: epigallocatechin gallate (EGCG), epigallocatechin (EGC), epicatechin gallate (ECG), 
dan epicatechin (EC). ${ }^{2}$ EGCG adalah komponen katekin yang paling poten, paling banyak terdapat dalam daun teh hijau dan secara kimia mempunyai aktivitas biologis yang paling kuat. ${ }^{3}$ EGCG dalam teh hijau mempunyai efek antiinflamasi, antioksidan, antibakteri, antiviral, antienzymatic effects, dan probiotik pada manusia dan hewan maupun studi in vitro. ${ }^{4}$ Penggunaan bahan yang memiliki efek antiinflamasi, antibakteri, dan kemampuan regenerasi sel sekaligus dalam satu formulasi akan sangat efektif dalam mempercepat proses penyembuhan luka. Berdasarkan khasiat tersebut, adanya kandungan EGCG dalam periodontal dressing yang digunakan secara klinis diharapkan dapat mempengaruhi proses penyembuhan luka dengan efek samping yang minimal pada pasien.

Proses penyembuhan luka merupakan proses dinamis yang meliputi fase inflamasi, fase proliferasi, dan fase maturasi. ${ }^{5}$ Proses penyembuhan luka melibatkan banyak unsur sel, sel utama yang terlibat adalah fibroblas. Sel fibroblas merupakan elemen selular yang banyak ditemukan pada jaringan ikat gingiva yang berproliferasi, aktif mensintesis komponen matriks pada proses penyembuhan luka, serta perbaikan jaringan yang rusak. ${ }^{6}$

Dalam praktek kedokteran gigi, untuk mempercepat proses penyembuhan luka pasca tindakan bedah periodontal diaplikasikan periodontal dressing. Penggunaan periodontal dressing bertujuan untuk memberikan kenyamanan kepada pasien dan melindungi permukaan luka. ${ }^{7}$ Periodontal dressing secara garis besar dibedakan menjadi dua jenis yaitu mengandung eugenol dan non-eugenol. Penelitian terdahulu memperlihatkan bahwa periodontal dressing yang mengandung eugenol menyebabkan inflamasi, jaringan nekrosis, memicu reaksi alergi, dan menunda terjadinya proses penyembuhan luka. Hal tersebut menyebabakan periodontal dressing non-eugenol lebih banyak dikembangkan. ${ }^{8}$ Berdasarkan sifat yang dimiliki oleh EGCG teh hijau, penambahan bahan tersebut dalam periodontal dressing dapat dimanfaatkan untuk mendapatkan efek bahan tersebut pada penyembuhan luka pasca bedah periodontal.

Tujuan penelitian ini adalah untuk membuktikan pengaruh penambahan EGCG daun teh hijau pada periodontal dressing terhadap jumlah sel fibroblas pasca perlukaan gingiva.

\section{METODE}

Jenis penelitian ini adalah penelitian eksperimental laboratoris dengan rancangan post test only control group design. Pembuatan ekstrak menggunakan metode maserasi dan identifikasi senyawa katekin (EGCG) secara kualitatif. Pembuatan periodontal dressing dilakukanan berdasarkan formula Baer, ${ }^{9}$ terdiri dari: pembuatan powder (mencampur rosin sebanyak 28,5 g dan zinc oxide sebanyak $21,5 \mathrm{~g}$ ) dan pembuatan pasta (mencampur hydrogenated fat sebanyak 47,5g dan zinc oxide sebanyak $2,5 \mathrm{~g}$ ), kemudian mencampur powder $50 \mathrm{mg}$ dan pasta $50 \mathrm{mg}$ sedikit demi sedikit sampai homogen. Pembuatan periodontal dressing formula Baer pada kelompok kontrol: periodontal dressing formula Baer yang sudah homogen diambil sebanyak 100mg tanpa ditambah EGCG daun teh hijau, sedangkan pembuatan periodontal dressing formula Baer modifikasi dengan penambahan ekstrak etanol daun teh hijau pada kelompok perlakuan: periodontal dressing formula Baer yang sudah homogen (100mg) diambil sebanyak 90mg kemudian ditambah dengan 10mg dari ekstrak daun teh hijau yang mengandung EGCG.

Penelitian ini telah mendapatkan persetujuan dan keterangan kelayakan etik berdasarkan dari Komisi Etik Penelitian Fakultas Kedokteran Gigi Universitas Gadjah Mada. Dua puluh empat ekor kelinci coba dibagi dalam 2 kelompok yaitu kelompok kontrol dan eksperimental. Setiap kelompok kemudian dibagi menjadi 3 sub kelompok berdasarkan waktu dekapitasi yaitu sesudah hari ke-3, 5, dan 7, sehingga jumlah sampel pada masing-masing sub kelompok adalah 4 ekor kelinci. Pengelompokan sampel dilakukan secara simple random sampling.

Masing-masing kelinci pada setiap dianestesi menggunakan ketamin. Dosis ketamin yang digunakan sesuai perhitungan adalah sebesar $24 \mathrm{ml} / \mathrm{g}$ BB. Punch biopsy berukuran $2 \mathrm{~mm}$ dengan kedalaman mencapai tulang alveolar pada mukosa labial rahang bawah regio insisivus, dilakukan pada kelinci yang talah teranestesi. Luka yang terjadi kemudian dibersihkan dengan larutan $\mathrm{NaCl} 0,9 \%$ dan $\mathrm{H}_{2} \mathrm{O}_{2} 3 \%$.

Periodontal dressing yang telah disiapkan, diaplikasikan pada daerah luka pasca punch biopsy gingiva kelinci. Luka pada kelompok perlakuan ditutup dengan periodontal dressing yang mengandung EGCG daun teh hijau, sedangkan pada kelompok kontrol ditutup dengan periodontal dressing tanpa EGCG daun teh hijau. Empat ekor kelinci dari tiap kelompok didekapitasi pada hari ke-3, ke-5 dan hari ke-7 setelah perlukaan. Setelah itu, jaringan luka dibuat preparat histologis dan dilakukan pengecatan dengan hematoksilin eosin untuk mengamati jumlah sel fibroblas.

Data yang diperoleh dari hasil pengamatan jumlah sel fibroblas merupakan data numerik dengan skala ratio, selanjutnya dihitung rerata jumlah sel fibroblas berdasarkan kelompok. Uji validitas data antara dua orang pengamat menggunakan uji Korelasi Pearson. Setelah data valid, data dilakukan uji normalitas terlebih dahulu untuk dengan menggunakan uji Saphiro-wilk $(\mathrm{N}<50)$ dan diuji homogenitasnya dengan uji Levene. Penelitian ini menggunakan uji ANOVA satu arah (one-way ANOVA) untuk mengetahui pengaruh penambahan EGCG daun teh hijau dalam periodontal dresssing terhadap jumlah sel fibroblas. 


\section{HASIL}

Hasil perhitungan pada hari ke-3, 5, dan 7, rerata jumlah sel fibroblas pada kelompok perlakuan berurutan adalah $30,13 \pm 0,9,27,55 \pm 1,1$ dan $24,63 \pm 0,4$ sel. Hasil ini lebih banyak daripada rerata jumlah sel fibroblas pada kelompok kontrol berurutan pada hari ke-3, 5 dan 7 yaitu 21,59 $\pm 0,5,20,63 \pm 0,3$ dan 19,38 $\pm 0,2$. Jumlah fibroblas pada terlihat paling banyak pada 3 hari pertama setelah perlukaan. Perbandingan rerata jumlah sel pada kedua kelompok tersebut dapat dilihat pada Gambar 1 dan secara histologis terlihat pada Gambar 2-4.

Berdasarkan hasil uji one-way ANOVA, diketahui bahwa terdapat perbedaan yang bermakna antara jumlah fibroblas antara kedua kelompok uji yang berhubungan dengan waktu perawatan dengan $p=0,0001$.

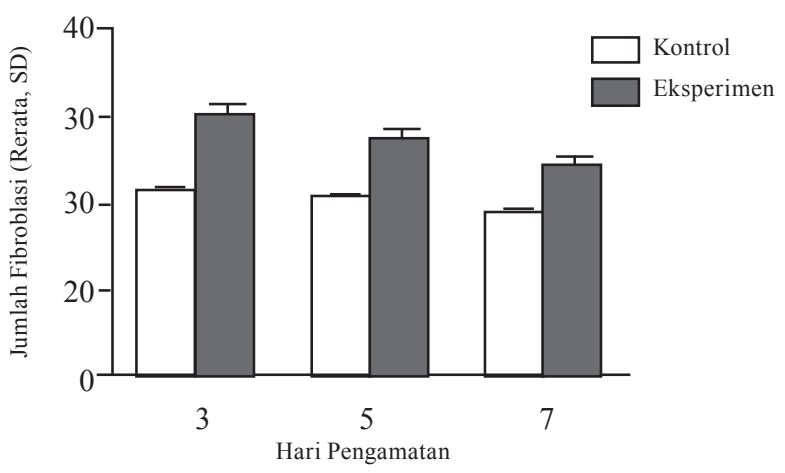

Gambar 1. Diagram rerata jumlah fibroblas antara kelompok kontrol dan eksperimen pada hari ke-3, 5 dan 7.

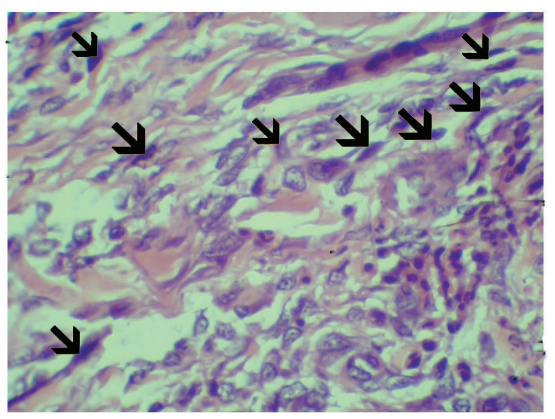

(A)

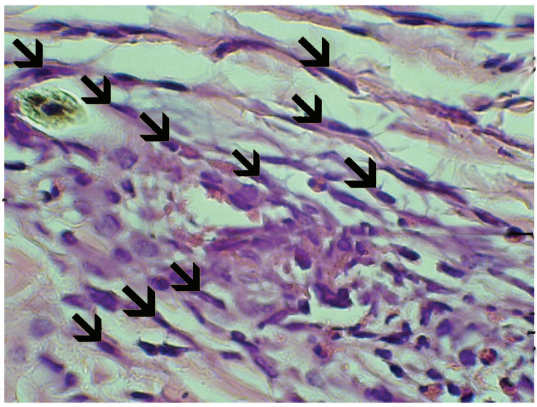

(B)

Gambar 2. Gambaran mikroskopik sel fibroblas (anak panah). (A) Kelompok kontrol dan (B) kelompok eksperimen pada hari ke-3 dengan pengecatan HE pembesaran 400x

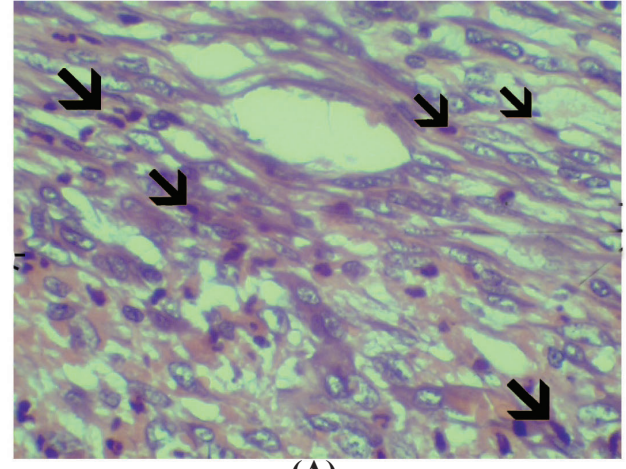

(A)

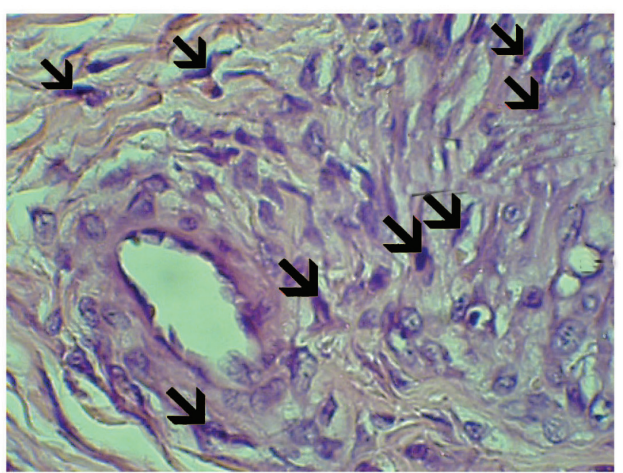

(B)

Gambar 3. Gambaran mikroskopik sel fibroblas (anak panah). (A) Kelompok kontrol dan (B) Kelompok eksperimen pada hari ke-5 dengan pengecatan HE pembesaran 400x

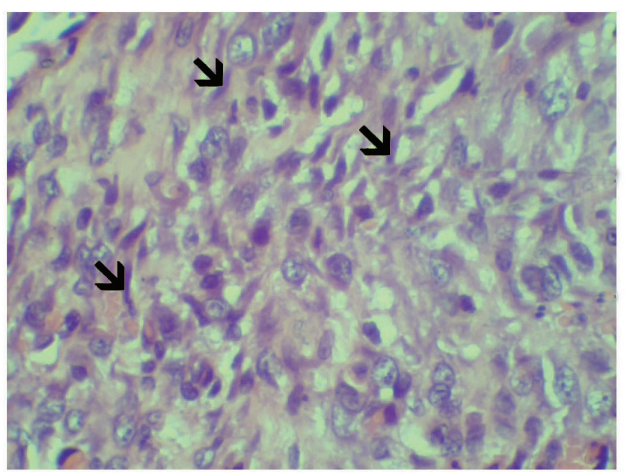

(A)

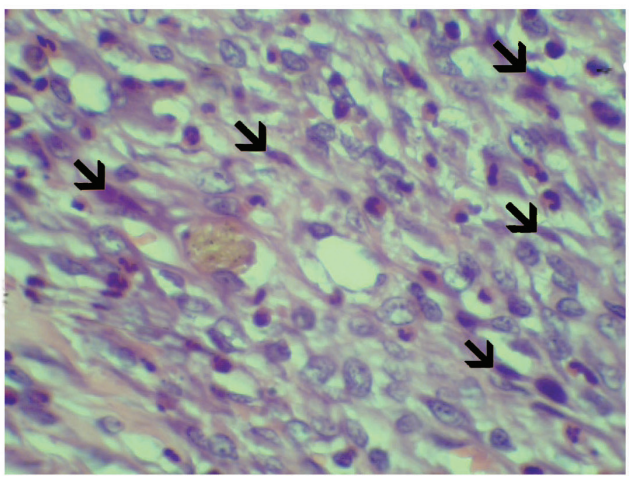

(B)

Gambar 4. Gambaran mikroskopik sel fibroblas (anak panah). (A) Kelompok kontrol dan (B) Kelompok eksperimen pada hari ke-7 dengan pengecatan HE pembesaran 400x 
Berdasarkan hasil uji one-way ANOVA, dapat diketahui bahwa parameter kelompok yang diinteraksikan dengan parameter hari memiliki nilai signifikansi sebesar $0,000(p<0,05)$ yang membuktikan adanya perbedaan yang bermakna dari jumlah sel fibroblas antara kelompok kontrol dan perlakuan dengan hari pengamatan.

\section{DISKUSI}

Penyembuhan luka pada seluruh jaringan setelah terjadi luka pada dasarnya mempunyai pola yang sama, tetapi memiliki beragam modifikasi penyembuhan, tergantung dari faktor - faktor intrinsik dan ekstrinsik yang meliputi beberapa tahap. ${ }^{10}$ Penyembuhan luka pasca punch biopsy berlangsung melalui beberapa tahapan biologis yang kompleks, penyembuhan ini diamati secara histologis dengan menghitung jumlah sel fibroblas untuk mengetahui proliferasi selnya. Sel fibroblas banyak ditemukan pada jaringan ikat gingiva yang berproliferasi pada proses penyembuhan luka.

Fibroblas merupakan sel yang aktif ketika terjadi respon terhadap luka dengan berproliferasi dan terjadi peningkatan fibrinogenesis sehingga menjadi agen utama dalam proses penyembuhan luka. Pembentukan sel fibroblas merupakan suatu tanda bahwa luka telah memasuki fase proliferasi. ${ }^{11}$ Hasil penelitian ini membuktikan jumlah sel fibroblas yang lebih banyak pada kelompok perlakuan dibandingkan dengan kelompok kontrol. Hal ini membuktikan penambahan EGCG daun teh hijau dapat mempercepat proses penyembuhan luka, melalui peran perantara makrofag yang merangsang faktor pertumbuhan sehingga meningkatkan proliferasi sel fibroblas. Makrofag memfagosit dan membunuh bakteri dan scavenge jaringan debris, selanjutnya melepakan dan mengaktifkan sitokin yang berupa IL-1 (interleukin 1), TNF (tumor necrosis factor), serta faktor pertumbuhan yang meliputi: Platelet Derived Growth Factor (PDGF), Transforming Growth Factor- $\beta$ (TGF- $\beta$ ), Fibroblast Growth Factor (FGF), dan Epidermal Growth Factor (EGF). Produk sitokin tersebut yang menstimulasi migrasi dan proliferasi sel fibroblas, serta produksi dan modulasi matriks ekstraselular. ${ }^{12}$

Pada hari ke-3 tampak bahwa rerata jumlah sel fibroblas pada kelompok perlakuan lebih banyak dibandingkan dengan kelompok kontrol (Gambar 1). Hal tersebut dikarenakan adanya kandungan EGCG yang merupakan komponen polifenol dalam daun teh hijau, dapat bersifat antiinflamasi dengan menghambat sintesis eikosanoid. Penghambatan ini akan menyebabkan penurunan kandungan asam arakidonat pada jaringan membran fosfolipid sel yang mengakibatkan terhambatnya pelepasan sejumlah mediator inflamasi seperti prostaglandin, leukotrin, dan tromboksan, sehingga akan menurunkan respon inflamasi. ${ }^{13}$ Jumlah sel fibroblas pada hari ke-3 paling banyak dibandingkan dengan hari pengamatan selanjutnya. Hal ini dikarenakan pada saat jaringan mengalami perlukaan, maka sel fibroblas yang akan segera bermigrasi ke arah luka, berproliferasi dan memproduksi matriks kolagen dalam jumlah besar yang akan membantu mengisolasi dan memperbaiki jaringan yang rusak. ${ }^{14}$

Jumlah sel fibroblas pada hari ke-5 mengalami penurunan dibandingkan dengan kelompok pengamatan pada hari ke-3, karena pada hari ke-5 terjadi penurunan proliferasi sel fibroblas untuk pembentukan serabut kolagen. Sintesis kolagen oleh sel fibroblas dimulai relatif awal pada proses penyembuhan hari ke 3-5 dan berlanjut terus sampai beberapa minggu tergantung ukuran luka. Pada hari ke-5 tampak bahwa rata-rata jumlah sel fibroblas pada kelompok perlakuan lebih banyak dibandingkan dengan kelompok kontrol. Hal ini disebabkan adanya kemampuan katekin (EGCG) daun teh hijau dalam proses regenerasi jaringan. Berkaitan dengan regenerasi jaringan, teh hijau juga kaya akan vitamin $C$ dan vitamin $B$, terutama tiamin dan riboflavin yang dibutuhkan oleh tubuh. Pemberian vitamin $\mathrm{C}$ dapat mempercepat proses penyembuhan pada luka melalui pembentukan sel fibroblas yang mensintesis kolagen, sehingga dapat mempercepat proses penyembuhan luka. ${ }^{4}$ Semua komponen polifenol dalam teh hijau juga merupakan antioksidan penting dan mempunyai aktivitas penangkapan radikal bebas yang kuat, seperti peroksida dan hidrogen peroksida yang berhubungan dengan fase inflamasi. ${ }^{15}$

Peran aktivitas antibakterial dari EGCG daun teh hijau pada proses penyembuhan luka sangat penting, karena substansi fenol dalam teh hijau mempunyai kemampuan untuk mendenaturasi protein bakteri, membentuk komplek dengan dinding sel bakteri dan merusak membran sel bakteri. Kematian bakteri mengakibatkan berkurangnya proses fagositosis bakteri oleh sel leukosit PMN. Hal tersebut mengakibatkan fase inflamasi berlangsung singkat, sehingga fase proliferasi juga berlangsung lebih awal. ${ }^{16}$

Pada hari ke-7 tampak bahwa jumlah sel fibroblas mengalami penurunan dibandingkan dengan jumlah sel fibroblas hari ke-5. Hal tersebut dikarenakan pada penelitian ini menggunakan hewan coba kelinci yang waktu penyembuhannya lebih cepat daripada manusia, sehingga proses sintesis kolagen oleh sel fibroblas dimulai relatif awal pada minggu pertama. ${ }^{17}$ Sesuai dengan pernyataan bahwa sintesis kolagen oleh sel fibroblas mencapai puncaknya pada hari ke-5 sampai ke-7. Sel fibroblas sudah mulai meninggalkan jaringan granulasi, warna kemerahan dari jaringan sudah berkurang, karena pembuluh sudah berkurang. ${ }^{18}$ Serat fibrin dan kolagen sudah bertambah banyak untuk memperkuat jaringan parut. ${ }^{14}$ Jumlah sel fibroblas kelompok perlakuan tidak berbeda jauh dengan kelompok kontrol, karena pengaruh efektivitas katekin daun teh hijau dalam periodontal dressing menurun. 


\section{SIMPULAN}

Penambahan EGCG daun teh hijau pada periodontal dressing dapat meningkatkan jumlah sel fibroblas dalam proses penyembuhan luka pasca perlukaan gingiva.

\section{DAFTAR PUSTAKA}

1. Hartoyo A. Teh dan khasiatnya bagi kesehatan, Yogyakarta: Kanisus; 2003. Indonesian.

2. Voung QV, Golding JB, Nguyen M, Roach PD. Extraction and isolation of catechins from tea. J Sep Sci. 2010;33:3415-28.

3. Mukhtar H, Ahmad N. Tea Polyphenols: Prevention of cancer and optimizing health. Am J Clin Nutr Suppl. 2000;71:16985-17028.

4. Shimamura T, Zhao WH, Hu ZQ. Mechanism of action and potential for use of tea catechin as an antiinfective agent. Anti-infective Agents Med Chem. 2007;6:57-62.

5. Sunyoto B, Istiadjid M, Hardjowasito W. Korelasi jumlah makrofag dan mast cell dengan macam penyembuhan luka pada kulit. Surabaya: Warta IKABI. 2000. [Internet]. [cited 2012 Jul 20]. Available from: http://ojs.lib.unair.ac.id/indexphp/fci/article/ viewfile/320/319. Indonesian.

6. Purnami T. Pengaruh khorhexidin sebagai obat kumur terhadap fibroblas pada proses penyembuhan luka mukosa rongga mulut. J Ked Gigi Mahasaraswati. 2003;1:73-7. Indonesian.

7. Newman MG, Takei HH, Carranza FA. Carranza's clinical periodontology. 10th ed. Philadelphia: W.B. Saunders Co; 2002.
8. Petelin M, Pogacnik A, Pavlica Z. Comparison of gingival wound healing with and without dressing in the beagle dog. Slove Vet Pers. 2003;40:99-106.

9. Prichard JF. Advanced periodontal disease: surgical and prosthetic management. 2nded. Philadelphia: WB Saunders; 1972.

10. Kabal-Dzik A, Stojko R, Szaflarska-Stojko E, Wroblewska-Adamerk I, Stojko J, Stawiarska-Pieta B. The influence of propolis balm on the healing process of experimentaly induced burn wounds. Ann Acad Med Siles. 2004;58:111-5.

11. Fawcett, DW, Jensh, RP. Bloom and Fawcett: a textbook of histology. 12th ed. Taylor \& Francis; 1997.

12. Gallin JI, Snyderman R. Inflammation: basic principles and clinical correlates. 3rd ed. Philadelphia: Lippincott Williams \& Wilkins; 1999.

13. Handajani J. Daya imunomodulasi daun teh hijau (Camellia sinensis). MIKGI. 2002;4:175-6. Indonesian.

14. Kumar V, Abbas AK, Fausto N. In: Robbins and Contran: Pathologic basis of disease. 7 th ed. Philadephia: Elsevier Saunders Inc; 2005.

15. Rohdiana D. Radical scavengers activity of tea polyphenol. Maj Far Ind. 2001;12:53-8.

16. Ismiyatin K. Konsentrasi minimal seduhan teh hijau Indonesia terhadap daya hambat pertumbuhan Streptococcus viridians. MIKG. 2000;34:52-5. Indonesian.

17. Samuelson DA. Textbook of veterinary histology. St. Louis: Saunders Elsevier; 2007.

18. Freedberg IM, Eiser AZ, Wolff K, Austen KF, Goldsmith LA, Katz SI. Fitzpatrick's dermatology in general medicine, $6^{\text {th }}$ ed, New York: McGraw-Hill; 2003. p. 2013. 